\title{
MIR126 wt Allele
}

National Cancer Institute

\section{Source}

National Cancer Institute. MIR126 wt Allele. NCI Thesaurus. Code C82070.

The human MIR126 wild-type allele is located in the vicinity of 9q34.3 and is approximately 84 bases in length. This allele, which encodes MIR126 pre-miRNA, plays a role in the regulation of gene expression. Alteration in the expression of this gene is associated with the development of cancers of the lung, liver, colon, breast and prostate as well as leukemias. 